\title{
A Review of Meningococcal Disease and Vaccination Recommendations for Travelers
}

\author{
Lidia C. Serra · Laura J. York · Amgad Gamil · Paul Balmer · Chris Webber
}

Received: December 6, 2017 / Published online: March 17, 2018

(C) The Author(s) 2018

\section{ABSTRACT}

\begin{abstract}
International travel has been steadily increasing since the middle of the twentieth century, including travel to regions with high levels of endemic meningococcal disease and areas with sporadic or sustained meningococcal outbreaks. Although invasive meningococcal disease (IMD) is relatively rare in travelers since the advent of quadrivalent meningococcal vaccines, it remains a serious concern because of its rapid progression, poor prognosis and outcomes, associated treatment delays, and the potential to precipitate outbreaks. Moreover, fatality occurs in up to $22 \%$ of those infected. This review will focus on IMD in travelers, with an emphasis on IMD epidemiology and the geographic regions of potential concern for
\end{abstract}

Enhanced content To view enhanced content for this article go to https://doi.org/10.6084/m9.figshare. 5929285.

L. C. Serra $(\varangle)$ · L. J. York · P. Balmer

Pfizer Vaccines, Medical Development, Scientific and Clinical Affairs, Collegeville, PA, USA

e-mail: Lidia.Olveira@pfizer.com

A. Gamil

Pfizer Vaccines, Global Medical Development, Scientific and Clinical Affairs, Dubai, United Arab Emirates

C. Webber

Pfizer Vaccines, Clinical Research and Development, Pearl River, NY, USA international travelers. As vaccination is the best approach for preventing IMD among travelers, currently available meningococcal vaccines and corresponding country-specific national meningococcal vaccination recommendations, where available, will be summarized by age and type of vaccine recommended. The use of the quadrivalent meningococcal vaccines, specifically the tetanus toxoid conjugate vaccine (including MenACWY-TT; Nimenrix $\left.^{\circledR}\right)$, as a protective measure against IMD in travelers will be emphasized.

Funding: Pfizer Inc.

Keywords: Adults; Invasive meningococcal disease; Meningococcal vaccines; Travelers

\section{INTRODUCTION}

Rates of global travel have been increasing since the 1950s. In 2000, 674 million individuals traveled internationally, with the number of travelers in 2010 and 2015 increasing even further to 950 and 1186 million, respectively [1]. Although invasive meningococcal disease (IMD) is relatively rare in travelers, it remains a serious concern because of its rapid clinical course, short time frame for diagnosis, difficulty in obtaining timely antibiotic treatment, potentially poor outcomes, and the ability of infection to spread rapidly among a population $[2,3]$. Even with appropriate medical care, the 
case-fatality rate remains high and can reach $22 \%$ [4], with approximately $20 \%$ of survivors experiencing debilitating long-term sequelae that include neurologic impairment, hearing loss, chronic pain, amputation, and skin scarring [5-7].

Although at least 12 serogroups of N. meningitidis have been reported, most cases of IMD are caused by serogroups A, B, C, W, X, and Y [8]. Currently, vaccination is the recommended approach for preventing IMD, with available vaccines targeting single serogroups or a combination of multiple serogroups; together, these vaccines can provide protection against 5 of the 6 major disease-causing meningococcal serogroups (i.e., A, B, C, W, and Y) [9]. Specifically, various formulations of conjugated quadrivalent ACWY vaccines are commonly used to target serogroups $\mathrm{A}, \mathrm{C}, \mathrm{W}$, and, $\mathrm{Y}$ and recombinant protein vaccines target serogroup $B$.

This review will focus on IMD in international travelers, with an emphasis on the geographic regions of potential concern and the importance of vaccination with quadrivalent conjugate vaccines as a preventative strategy for IMD. Country-specific national vaccination recommendations based on the traveler's country of origin will be discussed. Emphasis will be given to the quadrivalent vaccines, including the recently approved tetanus toxoid conjugate vaccine (MenACWY-TT, Nimenrix ${ }^{\circledR}$; Pfizer, Sandwich, UK), which is indicated for use in individuals $\geq 6$ weeks of age [10]. This review is based on previously conducted studies and information obtained from online databases and did not recruit human participants or utilize animals.

\section{GLOBAL EPIDEMIOLOGY OF INVASIVE MENINGOCOCCAL DISEASE IN TRAVELERS}

Regional IMD incidence at the traveler's destination is an important consideration when evaluating the overall risk of contracting IMD and should be taken into account when considering preventative strategies. Although travel to the African meningitis belt and the annual Hajj pilgrimage in Saudi Arabia currently pose two of the greatest risks for contracting IMD, there are other regions of particular concern to the global traveler; these are discussed in more detail below. Importantly, the prevalence of disease-causing serogroups can vary widely by region and year, so, from a preventative standpoint, it is important to understand the predominant disease-causing serogroups at the time of travel [11]. For instance, the recent emergence of serogroup $\mathrm{W}$ in a number of countries, coupled with its often atypical presentation, has made this a serious concern for international travelers; therefore, more detail regarding the emergence of serogroup $\mathrm{W}$ by region is also discussed briefly in the following sections.

\section{The African Meningitis Belt}

Although endemic in various regions across the globe, the IMD burden is greatest in the 22 countries comprising the "meningitis belt" of sub-Saharan Africa, which stretches from Senegal in the west to Ethiopia in the east [12]. In this region, IMD is hyperendemic, with the number of cases approaching 1000 per 100,000 population during the dry season. Epidemics in this region can occur annually and are characterized by a broad distribution across age groups. Outside of epidemic situations, the highest incidence of IMD in this region typically occurs in young children [13].

Between 1993 and 2012, the majority of IMD in the meningitis belt was due to serogroup A, which was the etiologic agent identified in $80 \%$ of the epidemics with approximately 1 million cases and 100,000 deaths [12]. In response to the medical need, a monovalent meningococcal A conjugate vaccine, MenAfriVac (PsA-TT; Serum Institute of India, Pune, India) was developed and prequalified for use in children and adults aged 1-29 years [14, 15]. In 2010, MenAfriVac was used in prophylactic vaccination campaigns in three African countries (Burkina Faso, Mali, and Niger) [16], and by 2014, no cases caused by serogroup A were identified in these countries [17]. In the face of declining serogroup A disease, serogroup W emerged as a predominant pathogen and, by 
2012, was responsible for 55\% of confirmed IMD in the region [18]. Cases of serogroup C were also increasing in the region. From December 2016 to June 2017, Nigeria experienced a large outbreak of IMD, and, of the 433 confirmed cases, $358 \quad(82.7 \%)$ were attributable to serogroup C [19]. This outbreak may represent the largest global outbreak of serogroup $\mathrm{C}$ to date, and a number of factors likely contributed to the large number of cases, including procedural and resource allocation inadequacies pertaining to specimen collection and identification, and delayed access to vaccines [19].

\section{Hajj}

A number of travel-related meningococcal outbreaks have been reported in the literature, and, of these, the largest and the most notable are those associated with the annual Hajj pilgrimage in Saudi Arabia. The Hajj is the largest annual mass gathering on Earth and attracts more than 2 million pilgrims annually [20]. Hajj pilgrims are geographically diverse, representing $>180$ different countries, with many elderly participants who commonly have underlying medical conditions that would predispose them to IMD [20-22]. During the 1987 Hajj, an outbreak of serogroup A resulted in an incidence rate of 640 cases per 100,000 pilgrims. During the 2000 and 2001 Hajj, the majority of cases of IMD were not attributable to serogroup A, as expected, but to a hypervirulent strain of serogroup $\mathrm{W}$, which before that time was of little epidemiologic concern [21].

In 2000, a total of 253 laboratory-confirmed IMD cases occurred in Mecca, Medina, and Jeddah, and, among these, $56 \%$ of cases occurred in travelers [23]. Of the 161 cases for which the serogroup was identified, 58\% were serogroup $\mathrm{W}$ and $37 \%$ were serogroup A [23]. This outbreak resulted in 70 deaths (case-fatality rate, 28\%) and the subsequent spread of serogroup $\mathrm{W}$ disease to at least 16 countries from the pilgrims returning from the Hajj [21, 23]. A retrospective study conducted in Saudi Arabia between 1999 and 2002 (encompassing the 2000 and 2001 epidemic years) identified 729 cases of IMD that were reported within the country, and, of these, $42 \%$ occurred in travelers and $58 \%$ occurred in the local population [24]. The majority of these cases were identified in children, with 59 and $39 \%$ occurring in children $<5$ and $<2$ years of age, respectively [24]. Together, this suggests that the Hajj pilgrimages of 2000 and 2001 featured an epidemiologic shift from serogroup A to W. Information on case-fatality rates among pilgrims, many of whom are diagnosed upon returning to their native countries, is not consistently reported; however, data available from the 2000 Hajj epidemic suggest a high casefatality rate associated with that outbreak, with reported rates ranging from $21 \%$ among pilgrims from Oman to $60 \%$ among pilgrims hospitalized in Mecca [25].

\section{Other Regions}

Transient and sporadic increases in IMD have also been noted globally in countries outside of the African meningitis belt and Saudi Arabia. Therefore, travelers should be aware of the local IMD epidemiology at any travel destination where increases in IMD cases have been documented. Some of these regions are discussed briefly below.

\section{Europe}

Although the IMD incidence in Europe is generally low, increases have been observed over the past decade. In 2015, the incidence of IMD in the European Union was 0.6 cases per 100,000 population, slightly down from the 0.7 cases per 100,000 population in 2010 . Countries with the highest number of cases per 100,000 population in 2015 were Lithuania (1.9), Ireland (1.5), the United Kingdom (1.4), and Malta (1.2) [26]. Despite low IMD incidence overall, certain serogroups are emerging as a concern in localized areas.

For example, since 2009, a clonal complex variant of serogroup $\mathrm{W}$ (cc11) has been causing increases in IMD in the United Kingdom [27]. During the 2013-2014 epidemiologic year, serogroup $\mathrm{W}$ accounted for $15 \%$ of IMD compared with $1.8 \%$ in $2008-2009$. This increase was due to the expansion of a single strain that 
primarily affected adults $\geq 45$ years of age in 2009-2010; however, by 2011-2012, cases were distributed across all age groups.

Serogroup C also emerged as a concern in Italy in 2015 and 2016, when 43 cases were reported in Tuscany within the span of 13 months; this was a substantial increase compared with the 12 and 16 cases reported in 2013 and 2014, respectively [28]. Ten of the 43 cases in Tuscany were fatal, and those infected ranged in age from 9 to 82 years. The molecular classification of the isolates obtained from these patients is ongoing [28].

\section{Central and South America}

In Central and South America, the annual incidence of IMD varies considerably, ranging from $<0.1$ cases per 100,000 population in Bolivia, Cuba, Paraguay, and Peru to almost 2 cases per 100,000 population in Brazil. However, it should be noted that surveillance and reporting are not uniform across countries, which may account for the wide range in incidence [11].

Serogroups B, C, Y, and $\mathrm{W}$ are all known to cause disease in this region. Although serogroups $\mathrm{B}$ and $\mathrm{C}$ are responsible for most cases of IMD, serogroup $\mathrm{W}$ is emerging as a cause of outbreaks in several countries [11, 29].

The prevalence of disease-causing serogroups varies widely by region and by year [11]. Between 2006 and 2011, serogroups B and C predominated across Central America, the Caribbean, and Mexico; however, in 2012, most IMD cases were caused by serogroups $\mathrm{B}$ and $\mathrm{Y}$ [11]. In the Andean region (Bolivia, Colombia, Ecuador, and Venezuela), the proportions of serogroup B and C cases increased between 2006 and 2012 as the relative proportion of serogroup Y declined [11]. In Brazil between 2006 and 2012, serogroup C caused most cases [11]. In the Southern Cone (Argentina, Chile, Paraguay, and Uruguay), serogroup B caused the majority of IMD in 2006; however, cases caused by serogroup $\mathrm{W}$ increased over time so that, by 2012, it was the predominant serogroup leading to IMD [11].

\section{Middle East}

In the Middle East, IMD incidence rates were highest in Sudan (2006) and Yemen (2005) with 13.26 and 4.74 cases per 100,000 population, respectively [25]. In countries that reported outbreaks, most were caused by serogroups A or $\mathrm{W}$, with the exception of Israel, where outbreaks were due to serogroups B or C [25]. Recent surveillance data from Kuwait cited a mean incidence rate of 0.5 per 100,000 population; the dominant serogroups were $\mathrm{W}$ and $\mathrm{B}$, accounting for 80 cases (32\% each). Serogroup B accounted for $34 \%$ of all cases in children $\leq 14$ years, and serogroup A accounted for $40 \%$ of all adult cases. Three outbreaks in Kuwait in 1987, 1989, and 2002 were caused by serogroups A, W, and B, respectively [30].

\section{Australia}

In Australia in 2013, the incidence of IMD was relatively low at 0.6 cases per 100,000 population, but beginning in 2014, the number of cases began to increase, and, by 2016 , an incidence rate of 1.1 cases per 100,00 population was reported [31]. In 2015, serogroup B was responsible for $64 \%$ of IMD cases, decreasing from previous years when serogroup B accounted for $75-88 \%$ of cases [32]. The proportion of cases due to serogroups $\mathrm{W}$ and $\mathrm{Y}$ have been rising in recent years, reaching $21 \%$ and $13 \%$, respectively, in 2015 [32]. Although IMD has been decreasing in New Zealand since 2002, the most recent surveillance data in 2013 reports an incidence rate of 1.5 cases per 100,000 population, which, although still relatively high, is the lowest annual IMD incidence rate in the last 20 years [33]. The average annual incidence rate in New Zealand between 2009 and 2012 was 2.5 cases per 100,000 population.

\section{North America}

In North America, Canada had a peak in IMD incidence in 2001 with 1.18 cases per 100,000 population, but, thereafter, incidence rates have leveled off and, from 2002 to 2011, IMD incidence ranged between 0.45 and 0.75 cases per 100,000 population [34]. In the United States, the incidence of IMD decreased from 0.61 to 0.18 cases per 100,000 population over the 
10-year period from 2003 to 2013 [35]. In 2016, the IMD incidence rate was 0.12 cases per 100,000 population, with serogroup $B$ being the most predominant (0.04 cases per 100,000 population) [36].

\section{Emergence of Serogroup W: a Concern for International Travelers}

Although vaccination against serogroup $\mathrm{W}$ is not broadly recommended for travelers outside of Saudi Arabia and the African meningitis belt [37], serogroup $W$, as noted above, is emerging as a global concern. Before 2000, serogroup W cases were sporadic [38]; however, increasing incidence rates since the 2000 Hajj have been observed in a number of countries, including England [39], South America [40, 41], Africa [42, 43], Australia [44], Canada [45, 46], and the United States [47]. Therefore, vaccination to prevent serogroup $\mathrm{W}$ infection should be an important consideration for international travelers.

In England, the number of serogroup W cases began to increase in 2009 and almost doubled in a single epidemiologic year, as evidenced by 95 cases in 2013-2014 compared with 176 cases in 2014-2015 [39]. More recently, serogroup $\mathrm{W}$ has been responsible for several IMD cases in teenagers, which have been characterized by an atypical gastrointestinal presentation that included nausea, vomiting, and diarrhea [40]. Among 15 cases diagnosed in teenagers aged 15-19 years between July 2015 and January 2016, 7 had mainly gastrointestinal symptoms, and of these, 5 died within $24 \mathrm{~h}$ of hospitalization [40]. This marked and notable increase in serogroup W cases in England was due to a single strain (ST11) that was also responsible for an increased IMD incidence in South America [40, 41].

Serogroup $\mathrm{W}$ has also been implicated in large meningococcal epidemics in Africa $[42,43]$. In one epidemic in The Gambia in 2012, an incidence rate of 1470 cases per 100,000 population (all serogroup W) was observed in children $<12$ months of age, and a $13 \%$ fatality rate was reported in this age group [43].
In Australia, the percentage of meningitis cases due to serogroup $\mathrm{W}$ increased from 4 to $30 \%$ during the 2-year interval between 2013 and 2015 [44]. Of the 22 cases that were reported, 9 cases occurred in adults $>70$ years of age, and the majority of isolates represented a single strain (ST11). An increased prevalence of IMD due to serogroup $\mathrm{W}$ has been noted in Canada between 2009 and 2016, with $18.8 \%$ of all cases attributable to serogroup $\mathrm{W}$ in 2016; the average percentage of serogroup $\mathrm{W}$ cases over the time period was $7.1 \%$ [46]. In the United States, where an outbreak of serogroup $W$ in 2008-2009 was linked to 14 cases of IMD in Florida, 4 of these were fatal [47].

Clinically, serogroup $\mathrm{W}$ has not only been associated with atypical gastrointestinal presentation but subtle differences in sequelae that differentiate it from other IMD-causing serogroups have also been observed, although data are currently limited [38]. These atypical sequelae associated with serogroup $\mathrm{W}$ disease include septic arthritis, pericarditis, bacteremia and sepsis, neonatal sepsis, chronic meningococcemia, pneumonia, and peritonitis. Serogroup W has also been associated with a high case-fatality rate $(16.3 \%)$ and infection of older adults (mean age, 53 years) at a higher rate [38].

\section{Other Considerations for Travelers}

Although regional IMD incidence is an important consideration when determining overall risk for international travelers, travelers should also consider a number of additional factors. For example, the traveler's occupation, length of stay, and activities undertaken during travel, particularly those that involve intensive interaction with indigenous populations and large groups, are also likely to influence the traveler's potential for contracting or spreading IMD. Some travelers may also be at higher risk for IMD due to certain medical conditions, such as inherited deficiencies in the complement pathway, asplenia, previous viral infections, and chronic underlying illness; smoking and crowded living conditions also pose a risk for IMD [48]. Therefore, in addition to regional IMD epidemiology at the traveler's destination, these 
items should be considered when evaluating the need for preventative vaccination strategies.

\section{AVAILABLE MENINGOCOCCAL VACCINES AND RECOMMENDATIONS FOR TRAVELERS}

\section{Quadrivalent Polysaccharide Conjugate Vaccines}

Currently, three different quadrivalent meningococcal vaccines-each containing capsular polysaccharides conjugated to a carrier protein-are available in various regions for the prevention of IMD caused by serogroups A, C, W, and Y (Table 1) [49]. MenACWY-DT (Menactra $^{\circledR}$, conjugated to diphtheria toxin; Sanofi Pasteur, Swiftwater, PA, USA) and MenACWYCRM (Menveo ${ }^{\circledR}$, conjugated to $C$ reactive protein; Novartis Vaccines and Diagnostics, Sovicille, Italy) were initially licensed in the United States in 2005 and 2010, respectively [49]. The third quadrivalent vaccine, MenACWY-TT (Nimenrix $^{\circledR}$, conjugated to tetanus toxoid; Pfizer), was first licensed in Europe in 2010 [50]. All vaccines have been approved for use in multiple countries and are well tolerated and immunogenic [49].

\section{Recombinant Protein Vaccines}

Unlike serogroups A, C, W, and $\mathrm{Y}$, the serogroup $B$ polysaccharide is structurally similar to molecules found on human neuronal cells, and thus can be considered a human self-antigen [51]. Therefore, serogroup B vaccine development has focused on targeting surface-exposed proteins. Using this approach, two recombinant-protein vaccines are currently available for the prevention of IMD due to serogroup B. MenB-FHbp (Trumenba ${ }^{\circledR}$, bivalent rLP2086; Pfizer, Philadelphia, PA) [52], targeting both subfamily A and subfamily $B$ variants of the conserved factor $\mathrm{H}$ binding protein (FHbp), was first licensed in the United States in 2014 [53], and, more recently, in Europe [54], Canada [55], and Australia [56]. A second serogroup B vaccine, MenB-4C (Bexsero ${ }^{\circledR}$,
4CMenB; GlaxoSmithKline Vaccines, Siena, Italy) [57], which includes three recombinant bacterial proteins (including subfamily B FHbp) and an outer membrane vesicle containing PorA [58], was first licensed in Europe in 2013 and is now licensed in several geographic regions $[59,60]$.

\section{National Meningococcal Vaccination Recommendations for Travelers from Their Country of Origin}

Vaccination is the best method for preventing meningococcal infection [9]. Currently, six countries including Australia [61], Bahrain [62], Canada [63], Saudi Arabia [64], the United Kingdom [65], and the United States [66] have national recommendations for meningococcal vaccination in travelers. Although there is some variability in country-specific guidance, specifically pertaining to the age of the vaccinees and the type of conjugate vaccine that is recommended (Table 2), there is general consistency across these guidelines regarding vaccination for travelers entering high-risk areas. For instance, all six of these countries recommend vaccination with a quadrivalent conjugate vaccine for travelers entering areas associated with an increased incidence of endemic or epidemic meningococcal disease that is caused by serogroups contained in the vaccine. Particular emphasis is given to vaccination for those traveling to the African meningitis belt and to Saudi Arabia for the Hajj and/or Umrah [61-64, 66, 67]. The United Kingdom also recommends vaccination for backpackers who are traveling in the "rough" and for those who are working with, or spending an extended period with, indigenous populations [65]. In addition to quadrivalent ACWY vaccination, the Public Health Agency of Canada recommends vaccination with a serogroup B vaccine for those entering areas with an increased incidence of serogroup B infection [63].

There are a number of resources available online for travelers documenting global and country-specific meningococcal disease epidemiology and vaccination recommendations (Table 3). For example, the World Health 


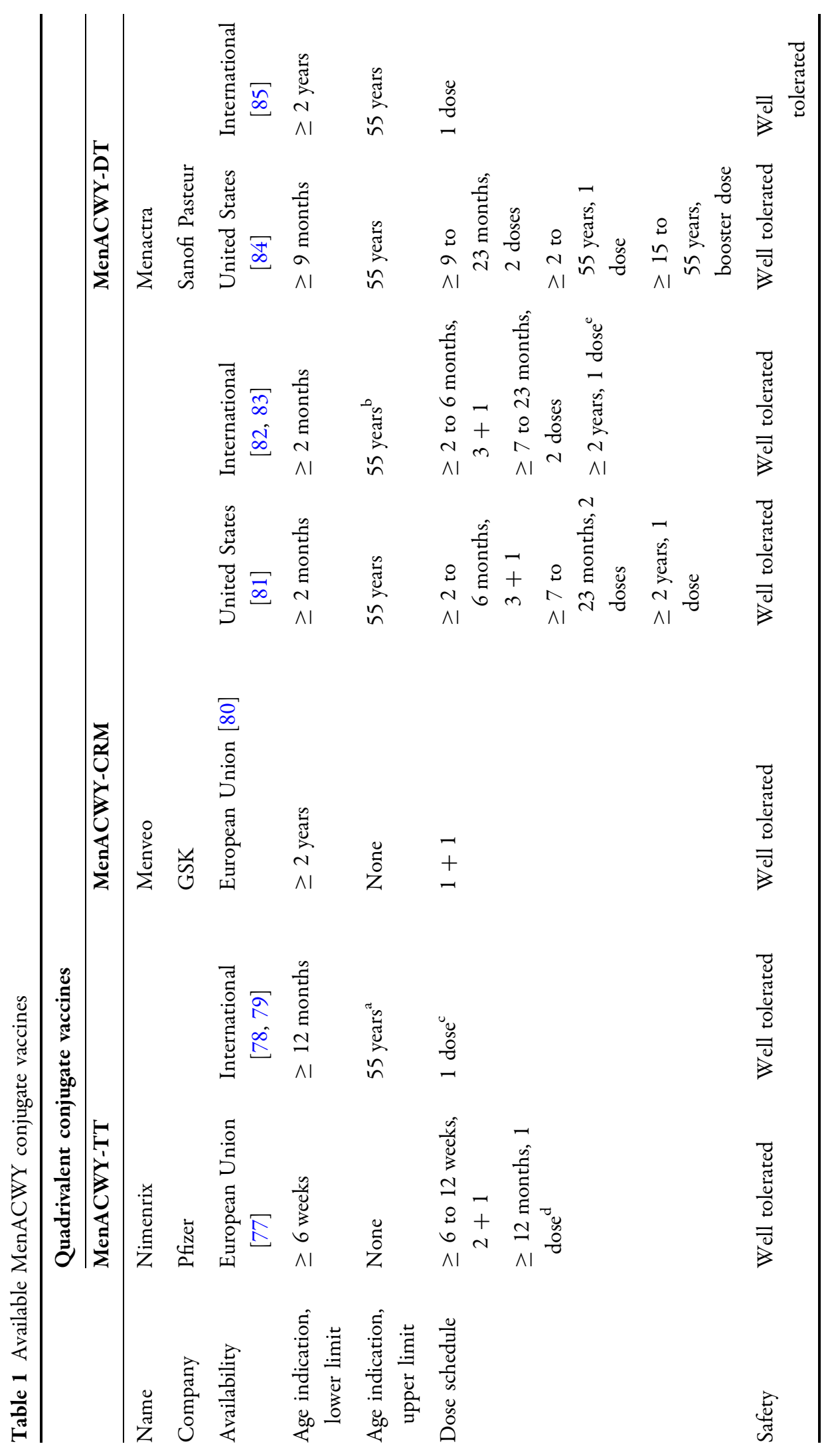




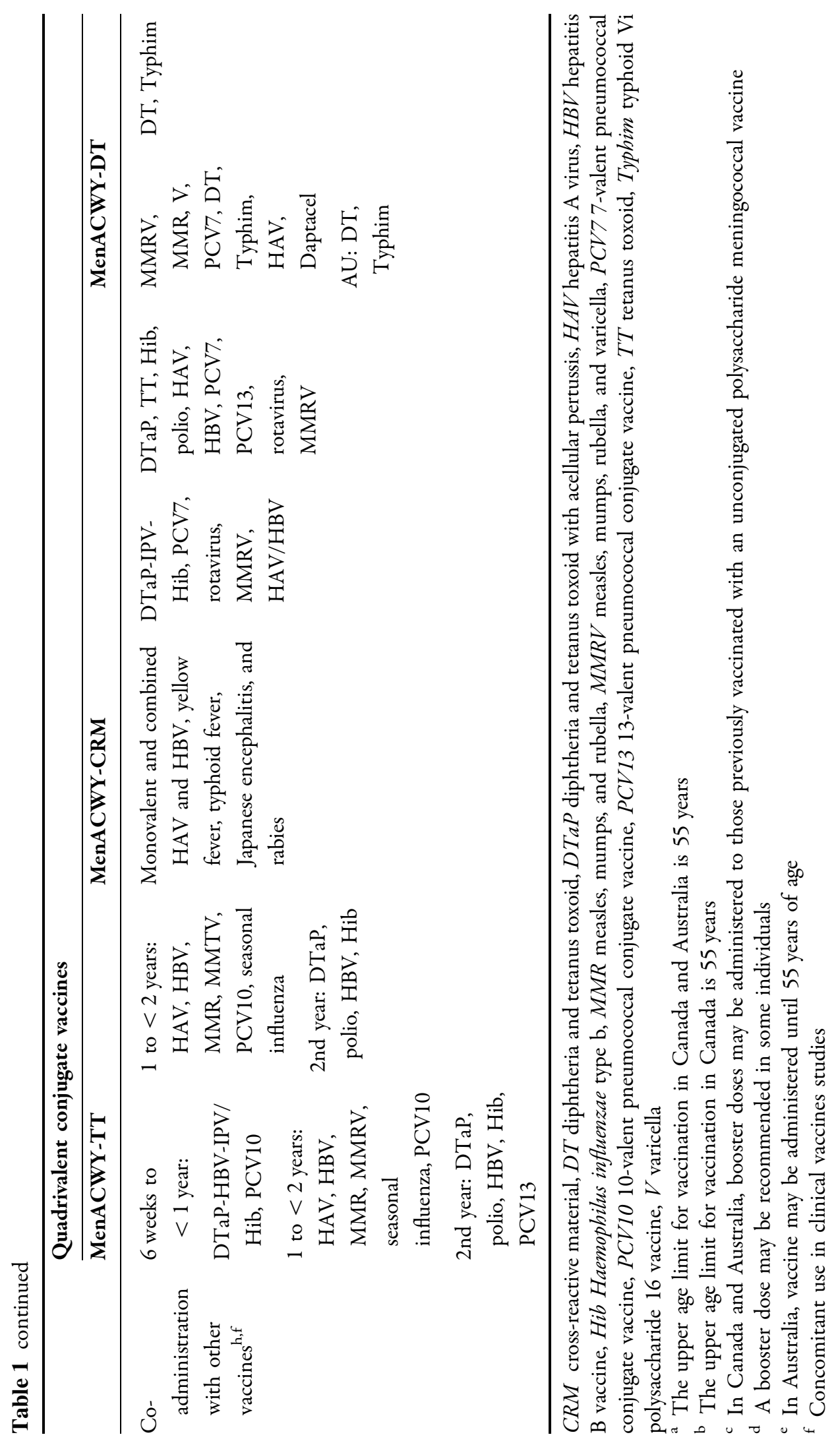


Table 2 Country-specific meningococcal vaccination recommendations for travelers

\begin{tabular}{ll}
\hline $\begin{array}{l}\text { Age/population } \\
\text { group }\end{array}$ & $\begin{array}{l}\text { Recommended meningococcal } \\
\text { vaccines }\end{array}$ \\
\hline
\end{tabular}

Australia [61]

2-6 months

7-11 months

12-23 months

$2-6$ years

$\geq 7$ years

MenACWY-CRM

MenACWY-CRM

MenACWY-CRM or

MenACWY-TT

MenACWY-DT MenACWY-

CRM, or MenACWY-TT

MenACWY-DT MenACWY-

CRM, or MenACWY-TT ${ }^{a}$

Bahrain [62]

$$
\geq 2 \text { years }^{\mathrm{b}}
$$

Canada [63]

$\geq 2$ months $^{\mathrm{c}}$

MenACWY-CRM; 4CMenB

Saudi Arabia [86]

$$
>2 \text { years }^{\mathrm{d}}
$$

MenACWY quadrivalent conjugate or polysaccharide vaccine

United Kingdom [65]

$\begin{array}{ll}\begin{array}{l}\text { Birth } \\ \text { to }<9 \text { months } \\ 9 \text { to }<12 \text { months }\end{array} & \text { MenACWY-CRM } \\ & \text { MenACWY-CRM or } \\ 12 \text { months-2 years } & \text { MenACWY-TT } \\ 2-4 \text { years } & \text { MenACWY-CRM or } \\ & \text { MenACWY-TT } \\ \geq 5 \text { years } & \text { MenACWY-CRM or } \\ & \text { MenACWY-TT preferred; } \\ & \text { MenACWY polysaccharide } \\ & \text { vaccine may be considered }\end{array}$

United States [66]

2 months

MenACWY-CRM

7-23 months

MenACWY-CRM or MenACWY-DT
Table 2 continued

\begin{tabular}{ll}
\hline $\begin{array}{l}\text { Age/population } \\
\text { group }\end{array}$ & $\begin{array}{l}\text { Recommended meningococcal } \\
\text { vaccines }\end{array}$ \\
\hline $2-55$ years & $\begin{array}{c}\text { MenACWY-CRM or } \\
\text { MenACWY-D }\end{array}$ \\
$\geq 56$ years & MenACWY-CRM or \\
(previously & MenACWY-D
\end{tabular}

$C R M$ cross-reactive material, $D T$ diphtheria toxin, $T T$ tetanus toxoid

${ }^{a}$ Quadrivalent conjugate vaccine is preferred; however, the quadrivalent polysaccharide vaccine is a suitable alternative for travelers aged $\geq 7$ years when the need for repeat doses is not anticipated

b A single-dose quadrivalent conjugate meningococcal vaccine is recommended to citizens at 2 years of age and is recommended for Hajj pilgrims and for travelers to certain countries; $1-2$ doses are recommended for individuals with certain hemoglobinopathies, congenital or acquired asplenia, presplenectomy, terminal complement deficiency, post bone marrow transplant, or certain cancers after the completion of treatment

${ }^{c}$ For those not previously vaccinated with MenACWYCRM or $4 \mathrm{CMenB}$

${ }^{d}$ Vaccination with quadrivalent vaccine is required for all citizens and residents of Medina and Mecca who have not been vaccinated during the past 3 years with a polysaccharide vaccine or during the past 5 years with a conjugate vaccine; all citizens and residents undertaking the Hajj who have not been vaccinated during the past 3 years with a polysaccharide vaccine or during the past 5 years with a conjugate vaccine; all Hajj workers, including individuals working at entry points or in direct contact with pilgrims, who have not been vaccinated in the past 3 years with a polysaccharide vaccine or in the past 5 years with a conjugate vaccine. Visitors from all countries arriving for the purpose of Umrah, pilgrimage (Hajj), or seasonal work must have proof of vaccination $\geq 10$ days and $<3$ years (polysaccharide vaccine) or $\geq 10$ days and $<5$ years (conjugate vaccine) before date of entry to Saudi Arabia

${ }^{\mathrm{e}}$ Even if vaccinated with Hib-MenCY-TT during infancy or childhood 
Table 3 Links to information pertaining to current meningococcal disease epidemiology and travel-related vaccination recommendations

\begin{tabular}{ll}
\hline Source & Website \\
\hline World Health Organization & http://www.who.int/csr/don/archive/disease/meningococcal_disease/en/ \\
$\begin{array}{l}\text { International Association for Medical } \\
\text { Assistance to Travelers }\end{array}$ & https://www.iamat.org/elibrary/view/id/1359 \\
$\begin{array}{l}\text { European Centre for Disease Prevention and } \\
\text { Control }\end{array}$ & https://ecdc.europa.eu/en/meningococcal-disease \\
$\begin{array}{l}\text { US Centers for Disease Control and } \\
\text { Prevention }\end{array}$ & https://www.cdc.gov/abcs/reports-findings/surv-reports.html \\
New Zealand Ministry of Health & https://surv.esr.cri.nz/surveillance/Meningococcal_disease.php \\
Australian Ministry of Health & http://www.health.gov.au/internet/main/publishing.nsf/content/cda- \\
& pubs-annlrpt-menganrep.htm \\
\hline
\end{tabular}

Organization maintains a database of meningococcal outbreaks and cases listed by the date of the most recent occurrence and the country of origin [68]. Another useful resource for travelers is the World Immunization Chart developed by the International Association for Medical Assistance to Travelers, which is continually updated and summarizes all global vaccination recommendations [37].

In addition, a number of societies have made similar recommendations for quadrivalent meningococcal vaccination for travelers entering high-risk areas, with the African meningitis belt and Saudi Arabia delineated as areas of potential concern. For example, the Malaysian Society of Infectious Diseases and Chemotherapy recommends vaccination with a conjugate meningococcal vaccine for pilgrims attending Hajj or Umrah, all travelers to high-risk areas, and adults with medical conditions that put them at high risk for infection (e.g., those with complement disorders or functional or anatomic asplenia) [69]. Because numerous societies put forth recommendations and there is no central repository for information, a summary of recommendations from societies is beyond the scope of the current review; however, it is advisable for travelers to check all recommendations in their country of origin when planning an itinerary.

\section{Recommendations at the Traveler's Destination for Those Entering High-Risk Areas, Primarily Saudi Arabia}

Since 2010, the Ministry of Health of Saudi Arabia and the Global Center for Mass Gathering Medicine has recommended that a quadrivalent conjugate meningococcal vaccination be administered to individuals 2-55 years of age residing in Saudi Arabia, and in 2013, a routine childhood vaccination program was implemented in that country [21]. However, due to the high cost, quadrivalent conjugate vaccines were initially recommended but not mandatory for international pilgrims [21]. Despite a lack of mandatory recommendations, overall vaccine coverage during the 2015 Hajj was high, with $91 \%$ of all pilgrims having received a quadrivalent vaccination, although vaccine coverage was $<70 \%$ in some countries [21]. In 2017, the Saudi Arabia Ministry of Health required quadrivalent meningococcal vaccination for all Hajj and Umrah pilgrims and for local pilgrims and seasonal workers [70].

\section{Importance of Recommending Vaccines that Protect Against Multiple Meningococcal Serogroups}

Considering the broad distribution of IMD serogroups worldwide and the presence and/or 
emergence of multiple serogroups within geographical regions, meningococcal vaccines that protect against multiple serogroups provide the best preventative option for travelers. Currently available quadrivalent ACWY conjugate vaccines would therefore not only confer protection to those traveling globally but would also be expected to reduce the risk of transmission, thus reducing the spread of disease at home and abroad. However, as noted previously, multiple formulations of quadrivalent ACWY polysaccharide conjugate vaccines are currently available in different regions around the globe. The availability, indication, dosing, co-administration with other vaccines, and safety/immunogenicity of the conjugate quadrivalent vaccines is set out in Table 1 . The text below will summarize the clinical data for the most recently approved vaccine, MenACWY-TT.

\section{Summary of Clinical Data for MenACWY-TT}

As evident from the information presented above, it is imperative that national meningococcal vaccination programs for travelers adapt to the variable nature of meningococcal disease at the traveler's destination; however, it is equally important that the recommending body make informed decisions regarding which vaccine to recommend when multiple formulations are available. To help inform these decisions, a brief summary of data available for MenACWY-TT is described.

The quadrivalent conjugated MenACWY-TT is licensed in the European Union and 43 additional countries, including Africa (18 countries), Asia (7 countries), Eastern Europe (3 countries), the Middle East (8 countries), North America (2 countries), Oceania (2 countries), and South America (3 countries). In some countries, including Europe, a 2-dose infant series of MenACWY-TT is indicated for infants beginning at 6 and 12 weeks followed by a booster dose, whereas a single dose is indicated for children aged > 12 months, adolescents, and adults [71]. In Canada and Australia, MenACWY-TT is indicated for individuals aged
12 months to 55 years $[72,73]$. MenACWY-TT is not currently licensed in the United States.

The immunogenicity and safety of MenACWY-TT have been established in clinical studies in individuals across all ages compared with other meningococcal vaccines, using an established correlate of protection [74]. Among toddlers, the percentage of subjects achieving seroprotection after 1 dose of MenACWY-TT can reach $100 \%$ [75], but 2 doses may be required to achieve adequate protection in younger children [76]. In adolescents and adults, $80-97 \%$ of individuals achieve protective titers against the four serogroups in MenACWY at 1 month post-vaccination after a single dose [74]. Persistence of antibody responses up to 5 years after administration of the MenACWY-TT primary series has also been demonstrated across age groups [74]. It has also been demonstrated that MenACWY-TT can be given concomitantly with other commonly administered vaccines, including the hepatitis $\mathrm{A}$ and $\mathrm{B}$ vaccines, the mumps/measles/rubella vaccine, the 10 -valent and 13 -valent pneumococcal conjugate vaccines, the diphtheria/tetanus/acellular pertussis vaccine, and the combined diphtheria, tetanus, acellular pertussis/hepatitis B/inactivated polio virus/haemophilus influenzae type $B$ vaccine.

MenACWY-TT is generally safe and well tolerated across age groups and has demonstrated an acceptable and consistent safety and reactogenicity profile in a pooled clinical study population that included 3079 toddlers (aged 12-23 months), 1899 children (aged $2-10$ years), 2317 adolescents (11-17 years old), 2326 adults (18-55 years old), and 274 older adults ( $\geq 56$ years old) [74]. Common local reactions included pain, redness, and swelling at the injection site, while common systemic events included drowsiness, fatigue, fever, headache, irritability, and loss of appetite. Safety was also demonstrated in 1052 infants receiving $\geq 1$ MenACWY-TT dose beginning at 6-12 weeks of age and in 1008 toddlers (aged 12-14 months) who received a booster dose [74]. 


\section{CONCLUSION}

Outside of Saudi Arabia, the decision of travelers to vaccinate against meningococcal disease rests on country-based recommendations and perceived risks. Recent changes in the global epidemiology of IMD, particularly a global increase in serogroup $\mathrm{W}$, have raised concerns in several countries worldwide and resulted in updated meningococcal vaccination recommendations, specifically the addition of conjugated MenACWY vaccine to existing recommendations. A quadrivalent conjugate vaccine, such as MenACWY-TT, can provide protection for travelers, especially those traveling to areas where the local meningococcal epidemiology involves multiple predominant serogroups or where the likelihood of epidemic outbreaks is high.

\section{ACKNOWLEDGEMENTS}

Funding. This work and the article processing charges were funded by Pfizer Inc.

Medical Writing Assistance. Writing support was provided by Susan E. DeRocco, PhD, and Regina E. Burris, PhD, of Complete Healthcare Communications, LLC, a CHC Group company, and was funded by Pfizer Inc.

Authorship. All authors meet the International Committee of Medical Journal Editors (ICMJE) criteria for authorship for this manuscript, take responsibility for the integrity of the work as a whole, and have given final approval to the version to be published.

Disclosures. Lidia C. Serra is an employee of Pfizer and may hold stock and/or stock options. Laura J. York is an employee of Pfizer and may hold stock and/or stock options. Amgad Gamil is an employee of Pfizer and may hold stock and/or stock options. Paul Balmer is an employee of Pfizer and may hold stock and/or stock options. Chris Webber is an employee of Pfizer and may hold stock and/or stock options.
Compliance with Ethical Guidelines. This review is based on previously conducted studies and information obtained from online databases and did not recruit human participants or utilize animals.

Open Access. This article is distributed under the terms of the Creative Commons Attribution-NonCommercial 4.0 International License (http://creativecommons.org/licenses/ by-nc/4.0/), which permits any noncommercial use, distribution, and reproduction in any medium, provided you give appropriate credit to the original author(s) and the source, provide a link to the Creative Commons license, and indicate if changes were made.

\section{REFERENCES}

1. World Tourism Organization. UNWTO tourism highlights, 2016. Available at: http://www.e-unwto. org/doi/pdf/10.18111/9789284418145. Accessed November 2, 2017.

2. Wilder-Smith A. Meningococcal disease in travelers: a rare but devastating disease. J Travel Med. 2010;17(suppl):1-2.

3. Pelton SI. The global evolution of meningococcal epidemiology following the introduction of meningococcal vaccines. J Adolesc Health. 2016;59(suppl):S3-11.

4. von Gottberg A, du Plessis M, Cohen C, et al. Emergence of endemic serogroup W135 meningococcal disease associated with a high mortality rate in South Africa. Clin Infect Dis. 2008;46:377-86.

5. Centers for Disease Control and Prevention. Meningococcal disease. Available at: http://www. cdc.gov/vaccines/pubs/pinkbook/downloads/ mening.pdf. Accessed March 23, 2017.

6. Swartz MN. Bacterial meningitis-a view of the past 90 years. N Engl J Med. 2004;351:1826-8.

7. Pace D, Pollard AJ. Meningococcal disease: clinical presentation and sequelae. Vaccine. 2012;30(suppl 2):B3-9.

8. Jafri RZ, Ali A, Messonnier NE, et al. Global epidemiology of invasive meningococcal disease. Popul Health Metr. 2013;11:11-7. 
9. Cohn AC, MacNeil JR, Clark TA, et al. Prevention and control of meningococcal disease: recommendations of the Advisory Committee on Immunization Practices (ACIP). MMWR Recomm Rep. 2013;62:1-28.

10. European Medicines Agency. Annex 1: summary of product characteristics (Nimenrix). Available at: http://www.ema.europa.eu/docs/en_GB/ document_library/EPAR_-_Product_Information/ human/002226/WC500127663.pdf, 2017. Accessed March 9, 2018.

11. Safadi MA, O’Ryan M, Valenzuela Bravo MT, et al. The current situation of meningococcal disease in Latin America and updated Global Meningococcal Initiative (GMI) recommendations. Vaccine. 2015;33:6529-36.

12. World Health Organization. Meningococcal disease in countries of the African meningitis belt, 2012-emerging needs and future perspectives. Wkly Epidemiol Rec. 2013;88:129-36.

13. World Health Organization. Control of epidemic meningococcal disease. WHO practical guidelines. 2nd edition. Available at: http://www.who.int/csr/ resources/publications/meningitis/whoemcbac983. pdf. Accessed November 2, 2017.

14. LaForce FM, Okwo-Bele J-M. Eliminating epidemic group A meningococcal meningitis in Africa through a new vaccine. Health Aff (Millwood). 2011;30:1049-57.

15. MenAfriVac (meningococcal A conjugate vaccine). Full prescribing information, Serum Institute of India, Pune, India, 2015.

16. Djingarey $\mathrm{MH}$, Barry $\mathrm{R}$, Bonkoungou $\mathrm{M}$, et al. Effectively introducing a new meningococcal A conjugate vaccine in Africa: the Burkina Faso experience. Vaccine. 2012;30(suppl 2):B40-5.

17. World Health Organization. Meningitis weekly bulletin, inter country support team-West Africa. Available at: http://www.meningvax.org/epidemicupdates.php. Accessed August 31, 2016.

18. Lingani C, Bergeron-Caron C, Stuart JM, et al. Meningococcal meningitis surveillance in the African meningitis belt, 2004-2013. Clin Infect Dis. 2015;61(suppl 5):S410-5.

19. Nnadi C, Oladejo J, Yennan S, et al. Large outbreak of Neisseria meningitidis Serogroup C-Nigeria, December 2016-June 2017. Morb Mortal Wkly Rep. 2017;66:1352-6.

20. Memish ZA, Yezli S, Almasri M, et al. Meningococcal serogroup A, C, W, and Y serum bactericidal antibody profiles in Hajj pilgrims. Int J Infect Dis. 2014;28:171-5.

21. Yezli S, Bin Saeed AA, Assiri AM, et al. Prevention of meningococcal disease during the Hajj and Umrah mass gatherings: past and current measures and future prospects. Int J Infect Dis. 2016;47:71-8.

22. Parker S. The Hajj: a constant travel destination amidst changing times. S Afr J Epidemiol Infect. 2010;25:14-8.

23. Lingappa JR, Al-Rabeah AM, Hajjeh R, et al. Serogroup W-135 meningococcal disease during the Hajj, 2000. Emerg Infect Dis. 2003;9:665-71.

24. Al-Mazrou YY, Al-Jeffri MH, Abdalla MN, Elgizouli SA, Mishskas AA. Changes in epidemiological pattern of meningococcal disease in Saudi Arabia. Does it constitute a new challenge for prevention and control? Saudi Med J. 2004;25:1410-3.

25. Ceyhan M, Anis S, Htun-Myint L, et al. Meningococcal disease in the Middle East and North Africa: an important public health consideration that requires further attention. Int $\mathrm{J}$ Infect Dis. 2012;16:e574-82.

26. European Centre for Disease Prevention and Control. Invasive meningococcal disease. Available at: https://ecdc.europa.eu/en/publications-data/ invasive-meningococcal-disease-annualepidemiological-report-2015. Accessed February 13, 2018.

27. Ladhani SN, Beebeejaun K, Lucidarme J, et al. Increase in endemic Neisseria meningitidis capsular group W sequence type 11 complex associated with severe invasive disease in England and Wales. Clin Infect Dis. 2015;60:578-85.

28. Stefanelli P, Miglietta A, Pezzotti P, et al. Increased incidence of invasive meningococcal disease of serogroup C, clonal complex 11, Tuscany, Italy, 2015 to 2016. Euro Surveill. 2016;21(12). https:// doi.org/10.2807/1560-7917.ES.2016.21.12.30176.

29. Abad R, Lopez EL, Debbag R, Vazquez JA. Serogroup $W$ meningococcal disease: global spread and current affect on the Southern Cone in Latin America. Epidemiol Infect. 2014;142:2461-70.

30. Husain EH, Barakat M, Al-Saleh M. Trends and variations in the epidemiology of meningococcal disease in Kuwait 1987-2013. J Infect Public Health. 2015;8:441-7.

31. Australian Government Department of Health. Invasive meningococcal disease national surveillance report. Available at: https://www.health.gov. au/internet/main/publishing.nsf/Content/ 5FEABC4B495BDEC1CA25807D001327FA/\$File/ 
19-June-2017-IMD-Surveillance-report.pdf. Accessed November 2, 2017.

32. Australian Government Department of Health. Australian meningococcal surveillance programme annual report, 2015, vol. 40. Australia: Canberra ACT; 2016.

33. New Zealand Ministry of Health. The epidemiology of meningococcal disease in New Zealand. Available at: https://surv.esr.cri.nz/PDF_surveillance/ MeningococcalDisease/2013/2013AnnualRpt.pdf. Accessed November 2, 2017.

34. Public Health Agency of Canada. Invasive meningococcal disease. Available at: http://www. phac-aspc.gc.ca/im/vpd-mev/meningococcal/ professionals-professionnels-eng.php. Accessed November 2, 2017.

35. Zhao J, Nelson TJ, Vu Q, Truong T, Stains CI. SelfAssembling NanoLuc luciferase fragments as probes for protein aggregation in living cells. ACS Chem Biol. 2016;11:132-8.

36. Centers for Disease Control and Prevention. Enhanced meningococcal disease surveillance report. Atlanta: GA; 2016.

37. International Association for Medical Assistance to Travelers. World Immunization Chart. Available at: https://www.iamat.org/elibrary/view/id/1359.

Accessed March 9, 2018.

38. da Silva L, deTora L, Malerczyk C, Memish Z. Emergence of Neisseria meningitidis W-135 in the context of other rare serogroups. Clin Invest. 2012;2:177-88.

39. Public Health England. Meningococcal disease: laboratory confirmed cases in England and Wales; invasive meningococcal $\mathrm{C}$ infections by epidemiological year and age group, England (1998 and 1999-2014 and 2015). Available at: https://www. gov.uk/government/publications/meningococcaldisease-laboratory-confirmed-cases-in-englandand-wales. Accessed November 2, 2017.

40. Campbell H, Parikh SR, Borrow R, et al. Presentation with gastrointestinal symptoms and high case fatality associated with group $\mathrm{W}$ meningococcal disease (MenW) in teenagers, England, July 2015 to January 2016. Euro Surveill. 2016;21:30175.

41. Lucidarme J, Hill DM, Bratcher HB, et al. Genomic resolution of an aggressive, widespread, diverse and expanding meningococcal serogroup $\mathrm{B}, \mathrm{C}$ and $\mathrm{W}$ lineage. J Infect. 2015;71:544-52.

42. Mueller JE, Gessner BD. A hypothetical explanatory model for meningococcal meningitis in the African meningitis belt. Int J Infect Dis. 2010;14:e553-9.
43. Hossain MJ, Roca A, Mackenzie GA, et al. Serogroup W135 meningococcal disease, The Gambia, 2012. Emerg Infect Dis. 2013;19:1507-10.

44. Carville KS, Stevens K, Sohail A, et al. Increase in meningococcal serogroup $\mathrm{W}$ disease, Victoria, Australia, 2013-2015. Emerg Infect Dis. 2016;22:1785-7.

45. Tsang RSW, Deeks SL, Wong K, Marchand-Austin A, Jamieson FB. Invasive serogroup W Neisseria meningitidis (MenW) in Ontario, Canada shows potential clonal replacement during the period January 1, 2009 to June 30, 2016. Available at: http://www.phac-aspc.gc.ca/publicat/ccdr-rmtc/ 16vol42/dr-rm42-12/ar-06-eng.php. Accessed March 27, 2017.

46. Tsang R, Hoang LM, Tyrrell GJ, et al. Increase in Neisseria meningitidis serogroup $\mathrm{W}$ invasive disease in Canada: 2009-2016. Available at: https://www. canada.ca/en/public-health/services/reportspublications/canada-communicable-disease-reportccdr/monthly-issue/2017-43/ccdr-volume-43-7-8July-6-2017/increase-neisseria-meningitidisserogroup-w-invasive-disease-canada-2009-2016. html. Accessed February 14, 2018.

47. Doyle TJ, Mejia-Echeverry A, Fiorella P, et al. Cluster of serogroup W135 meningococci, southeastern Florida, 2008-2009. Emerg Infect Dis. 2010;16:113-5.

48. Cohn AC, MacNeil JR, Clark TA, et al. Prevention and control of meningococcal disease: recommendations of the Advisory Committee on Immunization Practices (ACIP). MMWR Recomm Rep. 2013;62:1-28.

49. Ali A, Jafri RZ, Messonnier N, et al. Global practices of meningococcal vaccine use and impact on invasive disease. Pathog Glob Health. 2014;108:11-20.

50. Nimenrix ${ }^{\circledR}:$ EPAR—product information. European Medicines Agency. Available at: http://www.ema. europa.eu. Accessed July 28, 2017.

51. Finne J, Leinonen M, Makela PH. Antigenic similarities between brain components and bacteria causing meningitis. Implications for vaccine development and pathogenesis. Lancet. $1983 ; 2: 355-7$.

52. Trumenba ${ }^{\circledR}$ (meningococcal group B vaccine). Full Prescribing Information, Wyeth Pharmaceuticals Inc., a subsidiary of Pfizer Inc, Philadelphia, PA, 2016.

53. Folaranmi T, Rubin L, Martin SW, Patel M, MacNeil JR. Use of serogroup B meningococcal vaccines in persons aged $\geq 10$ years at increased risk for 
serogroup B meningococcal disease: recommendations of the advisory committee on immunization practices, 2015. Morb Mortal Wkly Rep. 2015;64:608-12.

54. European Medicines Agency. Committee for medicinal products for human use, summary of opinion: Trumenba. Available at: http://www.ema. europa.eu/docs/en_GB/document_library/Summa ry_of_opinion_-_Initial_authorisation/human/004 051/WC500224394.pdf. Accessed March 9, 2018.

55. Pfizer Canada. Trumenba, Product Monograph. Available at: http://www.pfizer.ca/sites/g/files/ g10037206/f/201711/Trumenba_PM_195550_05Oct-2017_E.pdf. Accessed March 9, 2018.

56. Australian Government Department of Health. Prescription medicines: registration of new chemical entities in Australia. Available at: https://www. tga.gov.au/prescription-medicines-registrationnew-chemical-entities-australia. Accessed March 9, 2018.

57. Bexsero $^{\circledR}$ (meningococcal group B vaccine). Full prescribing information, Novartis, Cambridge, 2016.

58. Bexsero ${ }^{\circledR}$. Summary of product characteristics. Siena, Italy: Novartis; 2013.

59. Vernikos G, Medini D. Bexsero ${ }^{\circledR}$ chronicle. Pathog Glob Health. 2014;108:305-16.

60. European Medicines Agency. Bexsero. Available at: http://www.ema.europa.eu/ema/index.jsp?curl= pages/medicines/human/medicines/002333/ human_med_001614.jsp. Accessed June 9, 2016.

61. Australian Government Department of Health. The Australian immunisation handbook. 10th ed. Canberra: Australian Technical Advisory Group on Immunisation; 2015.

62. Recommended schedule for the Expanded Program on Immunization, Bahrain. Kingdom of Bahrain Ministry of Health. Available at: https://www.moh. gov.bh/HealthInfo/Immunizations?lang=en. Accessed July 28, 2017.

63. Government of Canada. Canadian immunization guide. Part 4. Active vaccines. Available at: https:// www.canada.ca/en/public-health/services/ publications/healthy-living/canadianimmunization-guide-part-4-active-vaccines.html. Accessed May 2, 2017.

64. Ministry of Health Saudi Arabia. Health requirements for travellers to Saudi Arabia for pilgrimage to Makkah (2016/1437H Hajj) Available at: http:// www.moh.gov.sa/en/Hajj/Pages/
HealthRegulations.aspx. Accessed November 2, 2017.

65. Public Health England. Meningococcal. The green book. London: Public Health England; 2015.

66. MacNeil J, Meyer S. Meningococcal disease. Centers for Disease Control and Prevention. CDC health information for international travel 2016. New York: Oxford University Press; 2016.

67. Public Health England. Meningococcal: The green book, Chapter 22. Available at: https://www.gov. uk/government/publications/meningococcal-thegreen-book-chapter-22. Accessed November 2, 2017.

68. World Health Organization. Standardization and validation of serological assays for the evaluation of immune responses to Neisseria meningitidis serogroup A/C vaccines. Geneva, 8-9 March 1999. Available at: http://apps.who.int/iris/bitstream/ 10665/66298/1/WHO_V\%26B_99.19.pdf. Accessed April 4, 2016.

69. Malaysian Society of Infectious Diseases and Chemotherapy. Guidelines for adult immunisation. 2nd edition. Available at: http://docplayer.net/ 14756999-Malaysian-society-of-infectious-diseasesand-chemotherapy-guidelines-for-adult-immunisa tion-2nd-edition.html. Accessed November 2, 2017.

70. Saudia Arabia Ministry of Health. Meningococcal meningitis. Available at: https://www.moh.gov.sa/ en/Hajj/HealthGuidelines/HealthGuidelinesDuring Hajj/Pages/MeningococcalMeningitis.aspx. Accessed November 2, 2017.

71. NIMENRIX (meningococcal polysaccharide serogroups $\mathrm{A}, \mathrm{C}, \mathrm{W}-135$ and $\mathrm{Y}$ conjugate vaccine). Summary of product characteristics, Pfizer Ltd, Sandwich, Kent, 2017.

72. Bethea J, Makki S, Gray S, MacGregor V, Ladhani S. Clinical characteristics and public health management of invasive meningococcal group $\mathrm{W}$ disease in the East Midlands region of England, United Kingdom 2011 to 2013. Euro Surveill. 2016;21(24). https://doi.org/10.2807/1560-7917.ES.2016.21.24. 30259.

73. NIMENRIX (Meningococcal polysaccharide serogroups A, C, W-135 and Y conjugate vaccine). Full prescribing information, Pfizer Australia Pty Ltd, West Ryde NSW, Australia, 2016.

74. European Medicines Agency. Summary of Opinion $\left(\right.$ Menveo $\left.^{\circledR}\right)$. Available at: http://www.ema.europa. eu/docs/en_GB/document_library/Summary_of_ opinion_-_Initial_authorisation/human/001095/ WC500073647.pdf. Accessed November 2, 2017. 
75. Vesikari T, Forsten A, Boutriau D, et al. Randomized trial to assess the immunogenicity, safety and antibody persistence up to 3 years after a single dose of a tetravalent meningococcal serogroups $\mathrm{A}$, $\mathrm{C}, \mathrm{W}-135$ and $\mathrm{Y}$ tetanus toxoid conjugate vaccine in toddlers. Hum Vaccin Immunother. 2012;8:1892-903.

76. Klein NP, Baine Y, Bianco V, et al. One or two doses of quadrivalent meningococcal serogroups $\mathrm{A}, \mathrm{C}$, $\mathrm{W}-135$ and $\mathrm{Y}$ tetanus toxoid conjugate vaccine is immunogenic in 9- to 12-month-old children. Pediatr Infect Dis J. 2013;32:760-7.

77. Nimenrix ${ }^{\circledR}$, Summary of Product Characteristics (Meningococcal group A, C, W-135 and Y conjugate vaccine). Full prescribing information, Pfizer Ltd, Sandwich, Kent, 2018.

78. Nimenrix ${ }^{\circledR}$, Product information (Meningococcal polysaccharide serogroups $\mathrm{A}, \mathrm{C}, \mathrm{W}-135$ and $\mathrm{Y}$ conjugate vaccine). Full prescribing information, Pfizer Australia Pty Ltd, West Ryde NSW, 2016.

79. Nimenrix Product Monograph (Meningococcal polysaccharide groups $\mathrm{A}, \mathrm{C}, \mathrm{W}-135$ and $\mathrm{Y}$ conjugate vaccine). Full Prescribing information, Pfizer Canada Inc, Kirkland, 2016.

80. Menveo $^{\circledR}$ Summary of Product Characteristics (Meningococcal (groups A, C, Y and W-135) oligosaccharide diphtheria $\mathrm{CRM}_{197}$ conjugate vaccine). Full Prescribing Information, GSK Vaccines, Srl, Via Fiorentia, Italy, 2017.
81. Menveo $^{\circledR}$ (Meningococcal (Groups A, C, Y and W-135) Oligosaccharide Diphtheria CRM197 Conjugate Vaccine). Full Prescribing Information, Novartis Vaccines and Diagnostics, Inc., Cambridge, MA, USA, 2013.

82. Menveo ${ }^{\circledR}$ Product Information (Meningococcal (Groups A, C, W-135 and Y) Oligosaccharide CRM197 Conjugate Vaccine). Full prescribing information, GlaxoSmithKline Australia Pty Ltd, Abbotsford, Victoria, 2017.

83. Menveo $^{\circledR}$ Product Monograph (Meningococcal (Groups A, C, W-135 and Y) Oligosaccharide CRM197 Conjugate Vaccine). Full prescribing information, GlaxoSmithKline Inc., Mississauga, Ontario, 2017.

84. Menactra ${ }^{\circledR}$ (MCV4). Full prescribing information, Sanofi Pasteur, 2011.

85. Menactra ${ }^{\circledR}$ Australian Product Information (Meningococcal (Groups A, C, Y and W-135) Polysaccharide Diphtheria Toxoid Conjugate Vaccine). Full prescribing information, Sanofi-Aventis Australia Pty Ltd, Macquarie Park, NSW, 2014.

86. Health requirements for travellers to Saudi Arabia for pilgrimage to Makkah (2017/1438 Haji). Saudi Arabia Ministry of Health. Available at: http://www. moh.gov.sa/en/Hajj/Pages/HealthRegulations.aspx. Accessed July 28, 2017. 